\title{
Acute and Long-Term Behavioural Effects of MDMA in Adolescent Rats
}

\author{
E. Remmelink ${ }^{*}, 1,2$ and I.S. McGregor ${ }^{1}$ \\ ${ }^{I}$ School of Psychology, The University of Sydney, NSW, Australia \\ ${ }^{2} V U$ University, Amsterdam, The Netherlands
}

Keywords: MDMA, social interaction, conditioning, CPP, anxiety.

\section{INTRODUCTION}

Acute MDMA, even at low doses, increases social interaction in adult rats [1] while on the long-term its consumption produces a decrease in social interaction, an increase in anxiety and impaired object recognition memory $[2,3]$. This study investigated whether MDMA has the same effects in adolescent rats. Additionally, we investigated whether the preference of adolescent rats for MDMA was mediated by social context.

\section{METHODS}

Adolescent male Wistar rats (postnatal day $36+$ ) were injected daily with MDMA (5 $\mathrm{mg} / \mathrm{kg}$, intraperitoneally) or saline for 2 blocks of 8 days. In block A locomotor activity and social interaction were measured using Trackmate software 20 minutes after injection, while in block B preference for MDMA in a social or alone context was investigated in the conditioned place preference (CPP) paradigm. Rats were placed in the CPP compartments in pairs (social) or with a toy rat (alone). The order of test paradigm was counterbalanced over rats. One month after the final drug injection, rats were tested in the social interaction, emergence and novel object recognition test.

\section{RESULTS}

MDMA did not acutely increase social interaction and rats dosed with MDMA showed increasingly less social interaction with repeated administration. MDMA caused an acute hyperactivity effect and had a sensitisation effect on activity over time. Rearing and play behaviour were decreased by the drug. MDMA did not have any long-term effects on social interaction, anxiety or object recognition memory.

Rats dosed with MDMA did not prefer the social conditioned side over the alone conditioned side in the CPP paradigm. Rats even showed a significant aversion to the social side during the second CPP period.

*Address correspondence to this author at the VU University, Amsterdam, The Netherlands; Tel: 0293513544; Fax: 0293518023;

E-mail: e.remmelink@student.vu.nl

\section{DISCUSSION}

Contrary to its social effects in adult rats, MDMA does not appear to increase social interaction in adolescent rats. However, the effects of MDMA on locomotor activity, rearing and social play are consistent with previously performed studies in adolescent rats [4-6].

The low dose regime used in present study did not cause long-term impairments in social behaviour, anxiety or memory performance. Past research did find a long-term decrease in social interaction in young rats $[4,7]$. However, a different dose regime was applied. A comparable dose regime did lead to impairments in novel object recognition memory and increased anxiety in adult rats [3].

MDMA at a dose of $5 \mathrm{mg} / \mathrm{kg}$ is able to establish a place preference in adolescent rats [8]. Additionally, social play can create a place preference in juvenile rats [9]. However, since MDMA reduces play behaviour and because it cause hyperactivity, this might have led to the trend to an aversion of MDMA use in a social context.

\section{CONCLUSIONS}

MDMA did not cause the frequently observed acute increase in social interaction, but did lead to the typical pattern of hyperactivity, behavioural sensitisation, and decreased rearing and social play in adolescent rats. MDMA administration during adolescence had no long-term effects in adulthood. Therefore, our results might point to resilience to harmful effects of MDMA use in adolescent rats. The same might be true for use in adolescent humans.

\section{REFERENCE}

[1] Morley KC, McGregor IS. (+/-)-3, 4-methylenedioxymethamphetamine (MDMA, 'Ecstasy') increases social interaction in rats. Eur J Pharmacol 2000; 408: 41-9.

[2] Morley KC, Gallate JE, Hunt GE, Mallet PE, McGregor IS. Increased anxiety and impaired memory in rats 3 months after administration of 3, 4-methylenedioxymethamphetamine ("ecstasy"). Eur J Pharmacol 2001; 433: 91-9.

[3] van Nieuwenhuijzen PS, Kashem MA, Matsumoto I, Hunt GE, McGregor IS. A long hangover from party drugs: residual proteomic changes in the hippocampus of rats 8 weeks after gammahydroxybutyrate (GHB), 3, 4-methylenedioxymethamphetamine (MDMA) or their combination. Neurochem Int 2010; 56: 871-7. 
[4] Fone KC, Beckett SR, Topham IA, Swettenham J, Ball M, Maddocks L. Long-term changes in social interaction and reward following repeated MDMA administration to adolescent rats without accompanying serotonergic neurotoxicity. Psychopharmacology 2002; 159: 437-44.

[5] von Ameln N, von Ameln-Mayerhofer A. Atypical development of behavioural sensitization to 3, 4-methylenedioxymethamphetamine (MDMA, 'Ecstasy') in adolescent rats and its expression in adulthood: role of the MDMA chirality. Addict Biol 2010; 15: 3544.

[6] Homberg JR, Schiepers OJ, Schoffelmeer AN, Cuppen E, Vanderschuren LJ. Acute and constitutive increases in central serotonin levels reduce social play behaviour in peri-adolescent rats. Psychopharmacology 2007; 195: 175-82.

[7] Bull EJ, Hutson PH, Fone KC. Decreased social behaviour following 3, 4-methylenedioxy-methamphetamine (MDMA) is accompanied by changes in 5-HT2A receptor responsivity. Neuropharmacology 2004; 46: 202-10.

[8] Braida D, Iosue S, Pegorini S, Sala M. 3, 4 Methylenedioxymethamphetamine-induced conditioned place preference (CPP) is mediated by the endocannabinoid system. Pharmacol Res 2005; 51 : 177-82.

[9] Calcagnetti DJ, Schechter MD. Place conditioning reveals the rewarding aspect of social interaction in juvenile rats. Physiol Behav 1992; 51: 667-72.

(C) Remmelink and McGregor; Licensee Bentham Open.

This is an open access article licensed under the terms of the Creative Commons Attribution Non-Commercial License (http://creativecommons.org/licenses/ by-nc/3.0/) which permits unrestricted, non-commercial use, distribution and reproduction in any medium, provided the work is properly cited. 